\title{
COP21 Management: How to Link up International Governance with National Policy-implementation
}

\author{
Jan-Erik Lane \\ Correspondence: Jan-Erik Lane, fellow with Public Policy Institute, Belgrade. \\ Received: August 1, 2016 \\ doi:10.11114/bms.v2i3.1836 \\ Accepted: August 16, 2016 \\ Online Published: August 25, 2016 \\ URL: http://dx.doi.org/10.11114/bms.v2i3.1836
}

\begin{abstract}
It seems scientifically legitimate to move beyond the natural sciences' perspective upon he COP21 project. Can really social science theory be mustered to manage this global project for such a long time span? Or is it all make belief, decarbonisation writ large a figment of imagination? The natural sciences can deliver predictions about emissions and temperature as well as their interconnections. But only economics and social science have knowledge that is relevant to the implementation of the three goals of decarbonisation, subject to the requirement of economic growth. Neither implementation theory nor the management approach would render COP21 much chance of success. To understand COP21 management, one must analyse the country situations with regard to GDP-GHG(CO2) links as well as the mix of energy sources in each country.
\end{abstract}

Keywords: COP21 objectives, decarbonisation: goal i, goal ii and goal iii, risk of garbage can processes, super fund

\section{Introduction}

In Paris, the governments of the states of the world together with IGO:s and NGO:s committed themselves to the biggest management project in human history; complete decarbonisation during the 21 century. Could such an enormous change in energy really be accomplished-implementation success? And how is the COP21 process to be managed, interconnecting national governments with international governance?

The background of this unique coordination project covering almost all states and involving so many IGO:s and NGO:s is the fear of climate change in the coming decades with threat of global warming at levels that people can difficultly support, with dire consequences for both the economic and social systems. The COP is based upon a theory about global temperature that singles out energy as the crux of the matter, in particular the so-called anthropogenic green-house gases (GHG) and the $\mathrm{CO} 2$ emissions among them.

Yet, the essential theory behind COP stems from the natural sciences, including a host of hypothesis about GHG:s and temperature as well as projections for the future consequences of alternative warming levels - not uncontested ones, some of them with uncertainty. But where is the set of hypotheses from the social sciences about how to go about this huge project to save mankind and its fundamental living conditions?

The aim of this paper is to point about the problematic of global warming management. Unless they are paid attention to, we will face a dire implementation failure. The assumptions upon which COP management are built need to be spelled out and critiqued for veracity, as they may be make belief.

\section{The Global Energy Situation}

Energy is the capacity to do work. Lacking energy, no social system can operate, not even the family. The daily use of energy is almost astromical on a small Planet Earth, and it has had a trend of steady increases year by year. The governments of the states of the world have obliged the change the prevailing energy pattern profoundly in a short time period of a few decades.

Not only may all forms of energy be measured, but all these measures are translatable into each other - a major scientific achievement. One may employ some standard sources on energy consumption and what is immediately obvious is the huge numbers involved-see Table 1. 
Table 1. Energy Consumption 2015 (Million Tonnes of Oil Equivalent)

\begin{tabular}{lll}
\hline & Total & $\%$ \\
\hline Fossil fuels & 11306,4 & 86,0 \\
Oil & 4331,3 & 32,9 \\
Natural Gas & 3135,2 & 23,8 \\
Coal & 3839,9 & 29,2 \\
Renewables & 1257,8 & 9,6 \\
$\quad$ Hydroelectric & 892,9 & 6,8 \\
Others & 364,9 & 2,8 \\
Nuclear power & 583,1 & 4,4 \\
& 13147,3 & 100,0 \\
\hline
\end{tabular}

Source: BP Statistical Review of World Energy 2016)

Examining Table 1, one understands the size of the task of the decarbonisation policy effort. Complete decarbonisation would mean the elimination of the energy consumption of fossil fuels and traditional renewables. This is a herculean task, impossible simply. But the mix of energy usage will change during this century towards more of carbon neutral energy sources, but all the stylised energy projections provide fossil fuels with prominent share of energy markets.

The three steps in global COP management include:

- reversing the GDP-GHC(CO2) link from increasing to decreasing - GOAL I:

- cut CO2 emissions by $40 \&$ by 2030, from 2005 base - GOAL II;

- eliminate foossil fuels more or less by 2075 - GOAL III.

The question arisie of course; How this to be managed? And the costs involved? The main replies so far state: decentralisation to each nation and drawing upon the Stern Super Fund! Thus, each government or state has accepted this 3 steps goal and they can draw upon the expertise of IGO;s and NGO;s as well as ask for financial help from the Super Fund to be put in olace at some point in time. How to manage this uniquely gigantic project?

\section{Management Theories}

One may separate between at least four types of management theories, looking at developments since the beginnings of the 20th century with the giants Weber, Fayol and Taylor. Lots have been written about the development of the managerial approach, but here we simplify matters a little to get to the point that is relevant for the COP21. Thus, we:

1) Instrumental rationality, or efficieny: The basic paradigm is the means-end, to be employed for recommendations about improvement and change. How to organise things so that we have Max Outputs - Inputs - physical effectiveness? Or how to Max Revenues - Costs, when activities can be measured in money? This approach is normative, but not morally normative.

2) Ethical rationaity: How to design the best organisations in an overall meaning? Management has to take various asects of organisation into account, and not merely efficiency or productivity in a narrow sense. Thus, a list of evaluation criteris was developed and analysed: human relation dimensions like satisfaction, happiness, proudness etc., environmentalism, service to local comunties, lack or corruptability, etc. The overall assessment favour management in organisations constrained by market forces. Thus, socialist management was utlawed and cronyism criticised.

3) Real life management, or bounded rationality: Even if managers would try hard, which they do not always happen to do, they face cognitive limitations, barring comprehensive rationality of type 1). Instead they must concentrate upon a limit set of established objectives and rely upon a safe set of means, or technologies. H. Simon labelled this management style « standard operating procedures ».

4) The garbage can model of foolish management: March, once a collaborator of Simon, took the limitation on rational decision-making to its ultimate concept ual opposite with Norwegian Olsen, viz organised foolishness. If it were to be true of COP implementation, then we should not try this. We will wait and see what happens and how to react in a peacemeal fashion, i.e. the policy of resilience with Wildavsky. However elegant theoretically, the garbage can model always suffered from an ambiguity:

- is garbage can modelling necessarily true of management, public, private, international, etc.?

- or is this model merely a contingency, covering a few cases of policy failures and management errors? 
I believe the scoend tenet is defendable, but certainly not the first tenet.

Approaching COP implementation, one would still bet upon the management approach 1), searching for policies that eliminate fossil fuels for electricity production and bring down $\mathrm{CO} 2$ emissions in transportation. It can ce done, but will it be enough for the COP21 objectives.

\section{A New Framework of Anaysis}

I will argue that COP21 management face four sets of countries in different conditions:

i) weak governments in anarchic societies ;

i)) strong government in well-ordered societies :

iii) countries veru much reliant upon fossil fuels or traditional renewables ;

iv) countries with a balanced energy mix.

One can classify all the signatory states to the Paris Agreement on COP21 into these four sets. And the prediction is that governments in ii) and iv) may succeed with COP21 management by themselves. Countries in ii) and iii) will need assitance from international governance bodies, while countries in i) and iii) need massive financial assistance, albeit with the imminent risk of embezzement.

COP21 management has to take the following two factors into account:

$<$ GDP-GHG/CO2 link, energy mix), when it starts. And they affect the likelyhood of success or degree of goal attainment.

To sum up: COP21 management faces the following overall picture

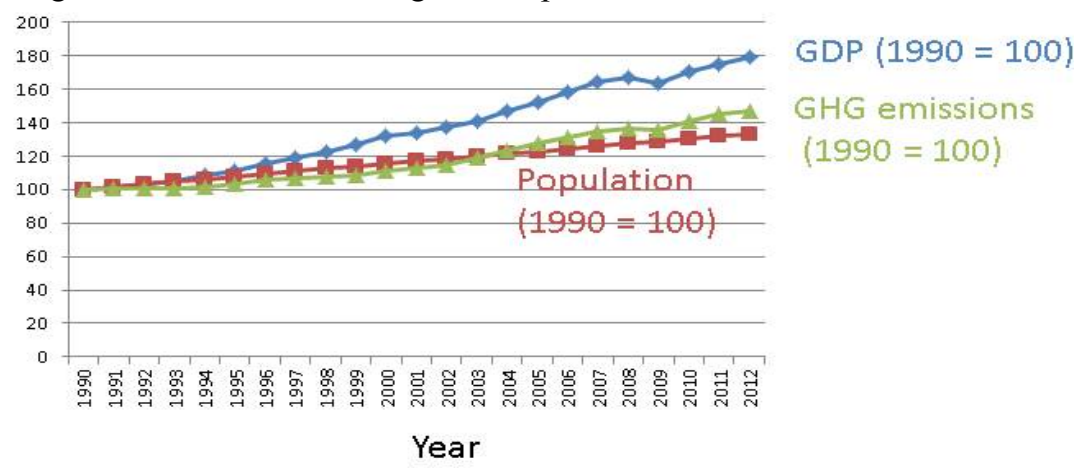

Figure 1. The Global Scene

COP21 management can do nothing about population growth increasing the $\mathrm{CO} 2$ :s directly and indirectly, but it may attempt to change energy consumption so that the link between GDP and $\mathrm{GHG}(\mathrm{CO} 2)$ is broken (Figure 2).

LN

(Total GHG Emissions / Kg) $\mathrm{CO} 2$ equivalent

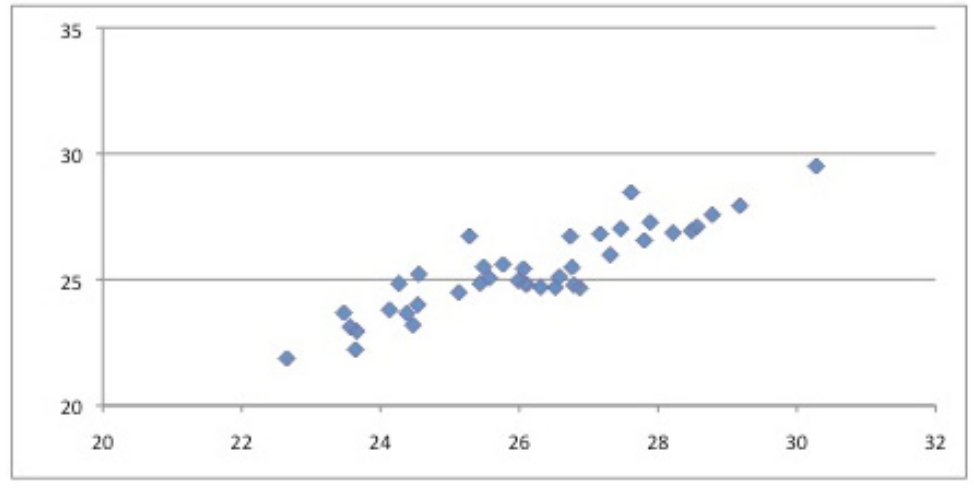

LN ( GDP / USD) (constant value 2005)

Figure 2. Gdp-Ghc Link Globally 
However, given the link in Figure 2, COP21 management cannot simply recommend that economic output be cut back Sach's sustainable economy. Decarbonisation is to be maximised, given the constraint that economic growth is NOT undermined. But the energy needs of human social systems just keep augmenting (Figure 3).

\section{GDP vs. Energy usage per capita $1990-2014$}

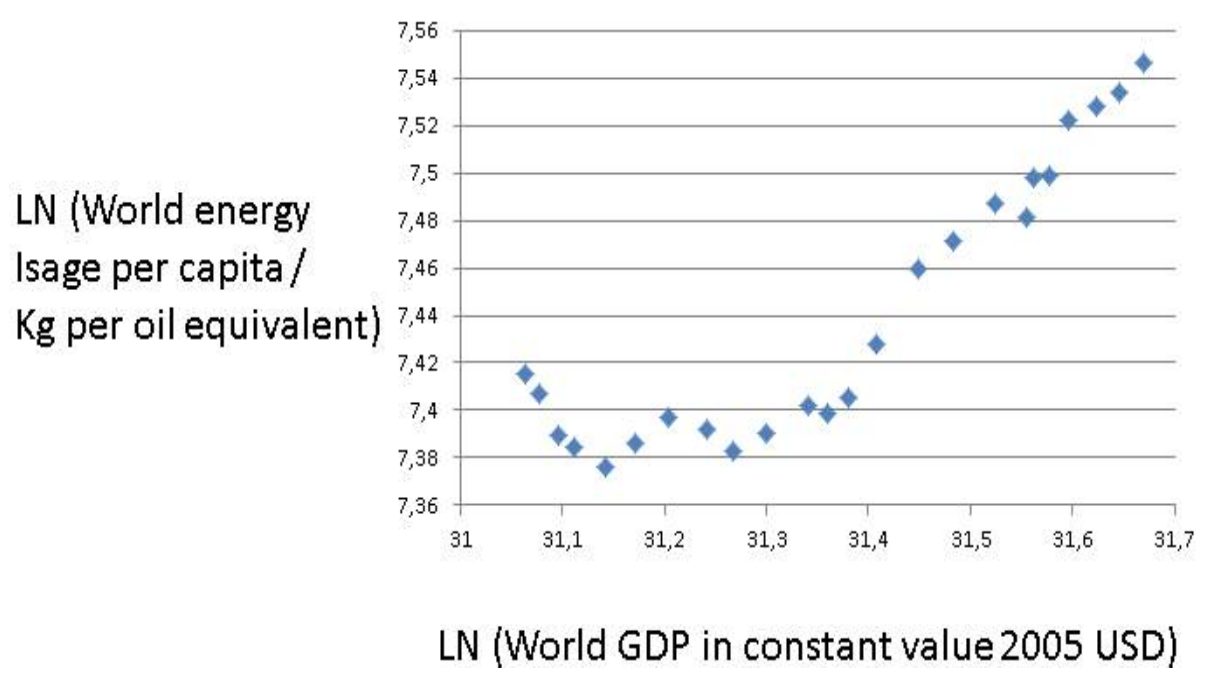

Figure 3. Economic Development and Energy per Person

Thus, the «noyeau »: Change energy pattern! But it can only be done by each country in the world. Let us distinhuish the promising cases from the not so promising ones, i.e. with regard to the possibility of rational management of COP 21 goals. Where is goal achievement likely?

\section{Promising Cases}

It is pehaps not astonishing that Nordic countries have broken the GDP-GHG(CO2) link and have conducted decarbonisation with admirable success. These are tiny countries and little affects the global scenarios above in Figures 1-3. But they often set the tone at international meetings on climate change. Let us examine Denmark (wind power) and Sweden (hydro power).

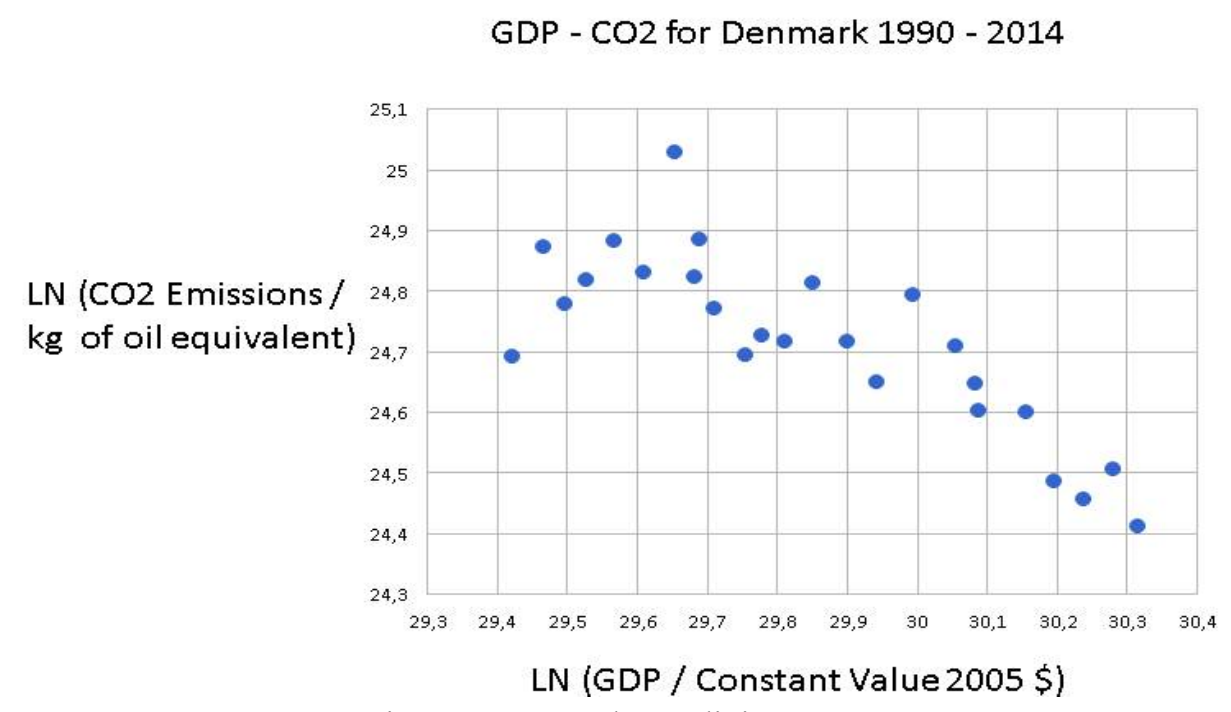

Figure 4. Denmark: Declining Curve

Danish governments and society has achieved a remarcable turn around, combining economic growth with the decrease of CO2:s. Yet, this accomplishment much advertised onöy satisfies GOAL I in COP21 management, i.e. the first objective for 2020 .

Denmark like any advanced capitalist county still relies upon fossil fuels, including coal (Figure 4). 


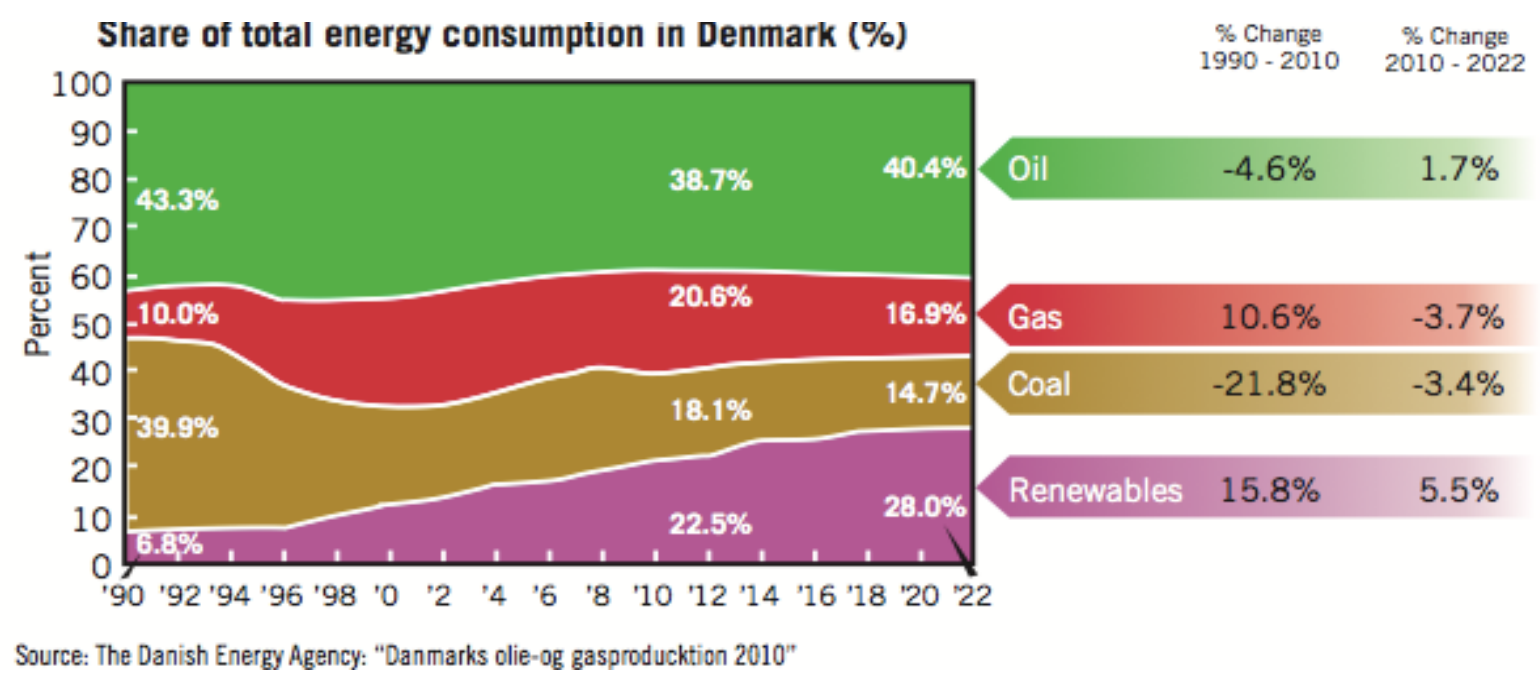

Figure 5. Energy mix in Denmark

Danish state and society must reduce oil and natural gas more to comply with the GOAL II in COP21 managementsolar power?

The Swedish curve for GDP-CO2:s looks much the same as Danish neighbour, downward and outward, but the Swedish energy mix is very different from Denmark's (Figure 6), as for instance Sweden is not a producer of oil and natural gas. However, Sweden presents a most diversified energy production and consumption pattern, which constitues a POSITIVE for accomplishing the GOAL I and II in time.

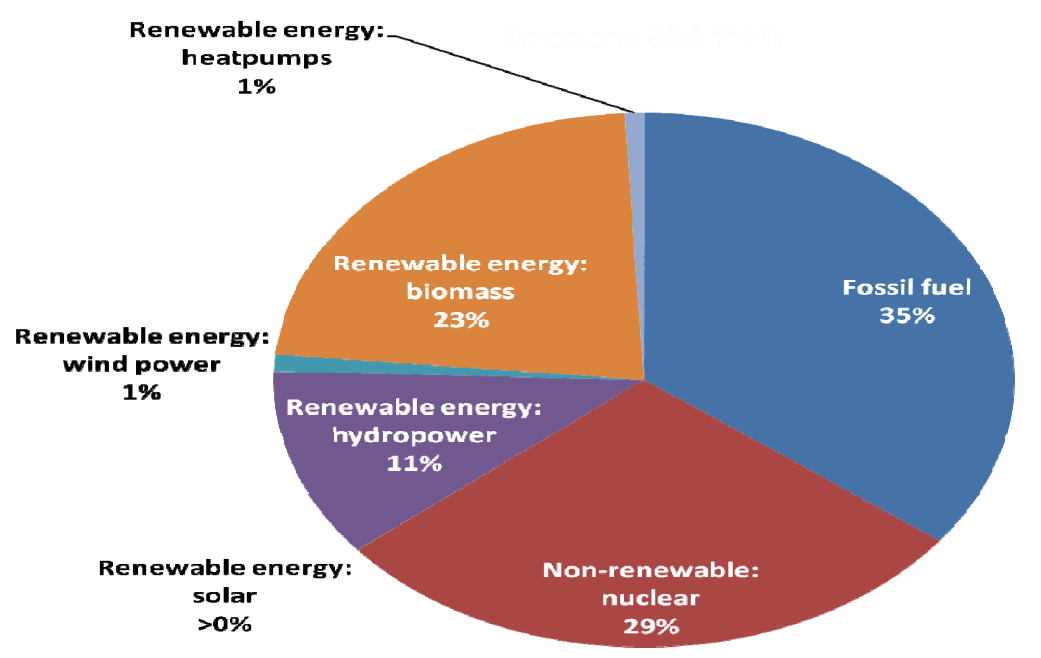

Figure 6. Energy mix in Sweden

The problem in Swedish energy management is policy ambiguity, reflecting the availability of many means too few goals. Sweden pursues an aggressive line of anti-nuclear power, either closing plants or restrain it by taxation. Thus, modern renewables like solar, wind and thermal power sources are given favourable treatment by the state. But this policy ambiguity characteristic of European environmentalism mixes up two entirely different kinds of green concern, viz the short-run fear of global warming with the long-run storage problem of atomic waste. Sweden has started use rely much upon burning waste and peats, despite their emissions.

The Nordic countries display good numbers on decarbonisation today and constitute a promise for the achievement of GOAL I and II though hardly for GOAL III. They have actually high GHG;s or CO2:s per capita, although not like the Gulf States (Qatar!). One man require in COP21 management that they reduce CO2:s even more than GOAL II, but this is to enter justice into the management model. Justice comes up naturally through contribution via the Super Fund to poor nations with huge emissions totally see but low on a per capita level.

Time to examine the giant country polluters, whether they have high or low emissions per person.

\section{Promising but Uncertain Cases}

For most countries hold that their emission of $\mathrm{CO} 2 \mathrm{~s}$ increases, as well as augments with the GDP. However, there are a 
few notable exceptions of decreases that are worth mentioning among the mature economies. We start with the US (Figure 7).

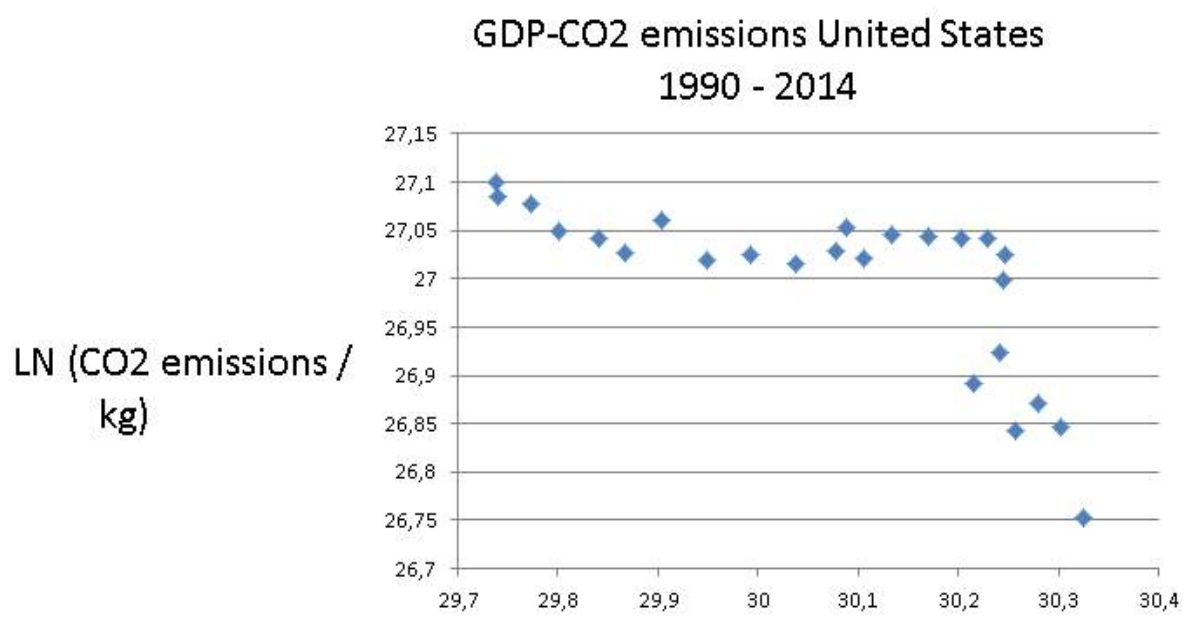

\section{LN (GDP / Constant Value 2005 USD)}

Figure 7. USA: LN (CO2 / Kg And LN (GDP / Constant Value 2005 USD) (Y= -0,32x + 36,7; R²=0,49)

Recently, the level of $\mathrm{CO} 2$ emission has been reduced significantly in the US. It reflects partly the economic crisis that began 2007, but the entire energy pattern is undergoing change, from coal towards modern renewables. Yet, the US remains the second largest polluter in the world. This $\mathrm{CO} 2$ reduction reflects that the US can draw upon a mixed bag of energies, including nuclear and hydro power, with solar power expanding rapidly (Figure 8).

\section{Primary energy consumption by source and sector, 2014 quadrilion Btu}

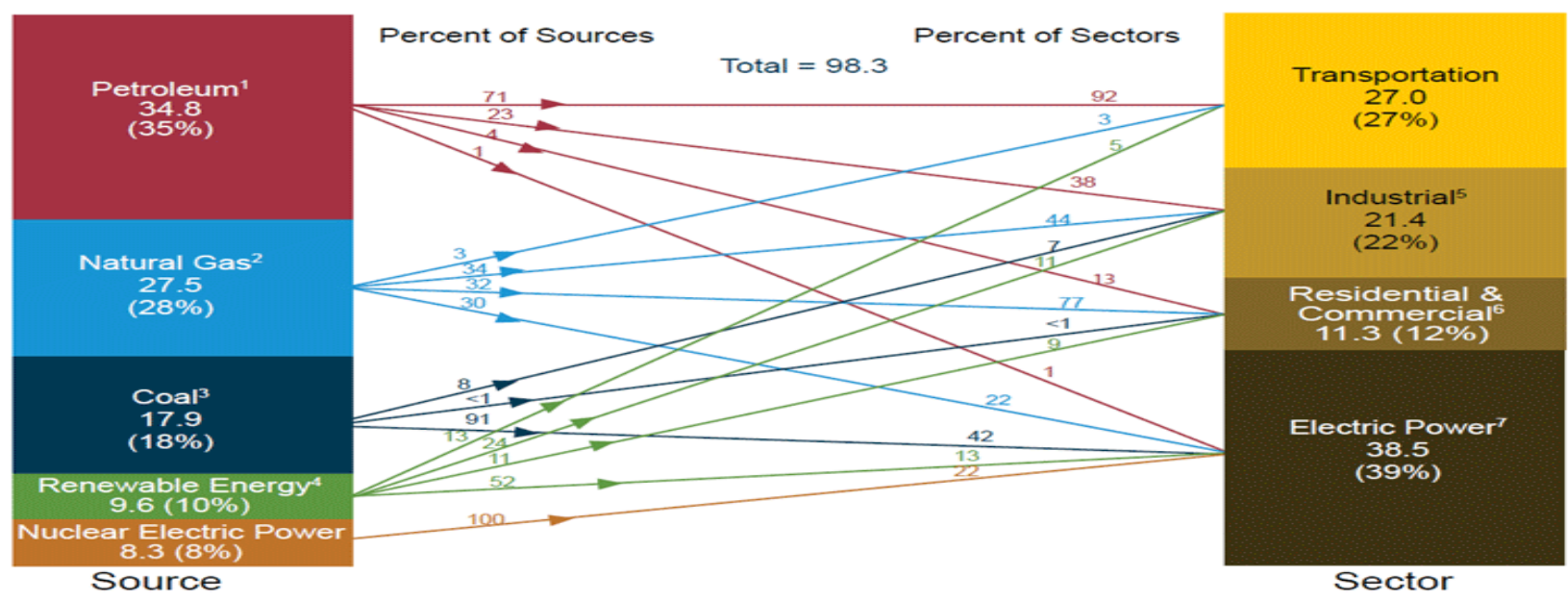

Endnotes:

1 Does not include biofuels that have been blended with petroleum-biofuels are included in

"Renewable Energy."

2 Excludes supplemental gaseous fuels.

3 Includes less than -0.1 quadrillion Btu of coal coke net imports.

4 Conventional hydroelectric power, geothermal, solar/photovoltaic, wind, and biomass.

${ }^{5}$ Includes industrial combined-heat-and-power (CHP) and industrial electricity-only plants

${ }^{6}$ Includes commercial combined-heat-and-power (CHP) and commercial electricity-only

plants.

${ }^{7}$ Electricity-only and combined-heat-and-power (CHP) plants whose primary business is to

sell electricity, or electricity and heat, to the public. Includes 0.2 quadrillion Btu of electricity net imports not shown under "Source."

Notes: Primary energy in the form that it is first accounted for in a statistical energy

balance, before any transformation to secondary or tertiary forms of energy (for example,

coal is used to generate electricity). - Sum of components may not equal total due to independent rounding.

Sources: U.S. Energy Information Administration, Monthly Energy Review (March 2015), Tables 1.3, 2.1-2.6.

Figure 8. Energy mixes in the US 
The US is still heavily dependent upon fossil fuels, as some 80 per cent comes there from, facing a challenger of reaching GOAL II. What is changing is the shale rock innovation, as more and more of energy is produced within the US, allowing even for condiderable export of petrolium. The shake oil and gas revolution may though not promote decarbonisation. Further reduction of $\mathrm{CO} 2$ :s may meet with firm resistance from the Republican House of Congress, which may oppose the COP21 Agreement, like presidential candidate D. Trump. However, solar power should be attractive in many US states, both in micro use in households and large plant use.

Not only coal consumption is being decreased but also atomic power is cut back, as it cannot compete with energy from shale rock. Yet, when solar and wind power falters, natural gas enters the picture. Solar plants take enormous amounts of space. Energy policy-making is most active in Washington, involving a complex system of tax deductions and returns.

The advent of shale oil and gas has changed the entire energy markets, lowering the price of oil most substantially. This implies not only that there will be no Hubbert peak oil for the world, but also that switching to renewable energy source will be extremely expensive, relatively speaking compared with shale oil and gas. When petroleum is abundant, then investments in carbon neutral power sources may be non-lucrative and require massive state subsidies.

Figure 20 shows how important energy is to the entire US society, including for its superpower position. When further reductions in CO2:s threaten vital national interests, the US like other nations will no doubt employ fossil fuel-

Another interesting country is the largest EU economy, namely Germany. Figure 9 shows a marked decrease in $\mathrm{CO} 2$ emissions.

\section{GDP-CO2 emissions Germany}

$1990-2014$

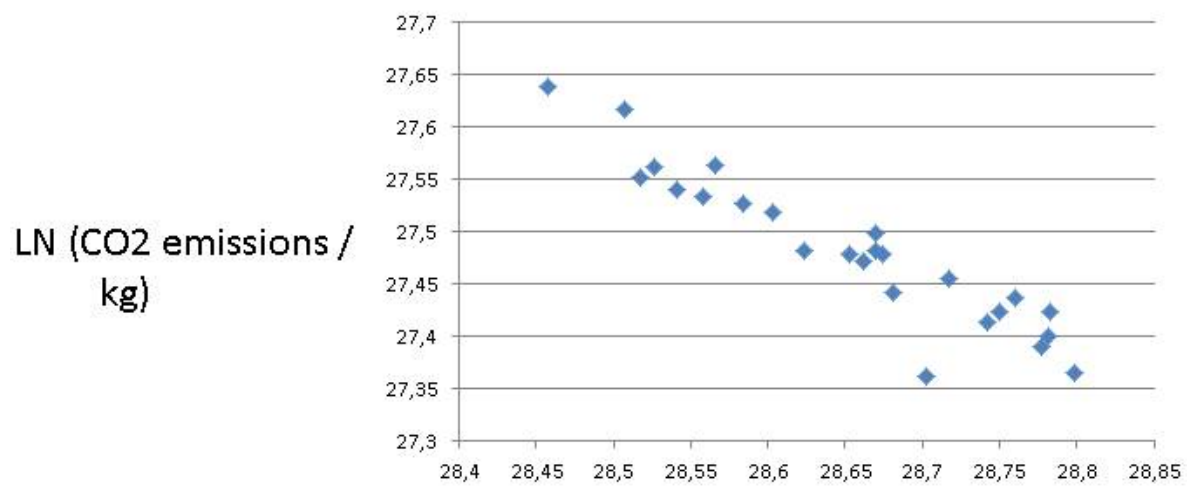

LN (GDP / Constant Value 2005 USD)

Figure 9. Germany: LN (CO2 / Kg and LN (GDP / Constant Value 2005 USD) ( $y=-0,69 x+47,3 ; \mathrm{R}^{2}=0,88$ )

The German data show an impressively consistent decreasing trend, which is not to be found with many countries, if at all. How come that Germany has succeeded in a short time span to reduce CO2:s? Germany needs massive amounts of energy for industry and transportation, but it has decided to phase out nuclear power. Can really the domestic employment of renewables satisfy this giant's demand for electricity? German energy policy - ENERGIWENDE - is spectacular comparatively speaking, but it also appears risky indeed.

It is true that nuclear power and renewables has made it possible for Germany to decrease its CO2:s much, but the country is still dependent upon fossil fuels, especially coal and oil - almost $60 \%$. What will happen with the nuclear power stations are phased out in 2022 is that most likely the $\mathrm{CO} 2$ emissions will start going up again. To replace nuclear power with solar and wind power on a truly massive scale will be difficult to say the least. Already, Germany uses more coal from Columbia and gas from Russia.

The German energy policy is causing much stir, because the losers - nuclear industry and coal power interests-want compensation that will run into billions of dollars, if not more.

Interestingly, also France has like Germany managed decarbonisation to some extent (Figure 10)). It reflects its unique energy mix, relying much upon nuclear power in a comparatively unique way. 


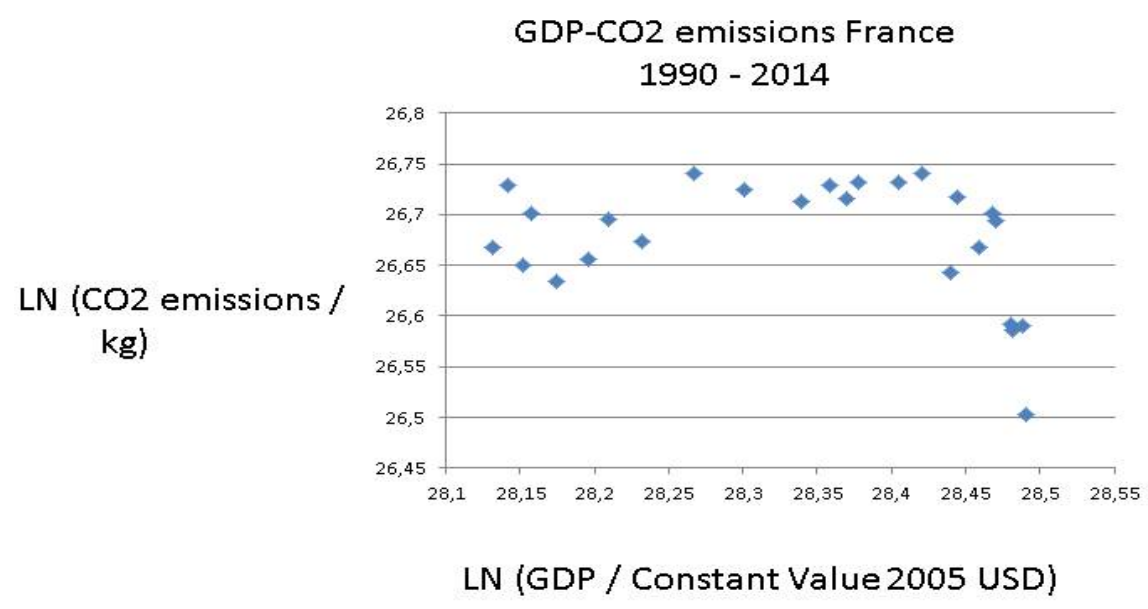

Figure 10. France $\left(y=-0,13 x+30,4 ; R^{2}=0,08\right)$

Yet, France has decided to diminish its reliance upon nuclear power. But how will it be replaced by other sources of energy? Figure 11 informs about the reliance upon fossil fuels in Germany and France too.

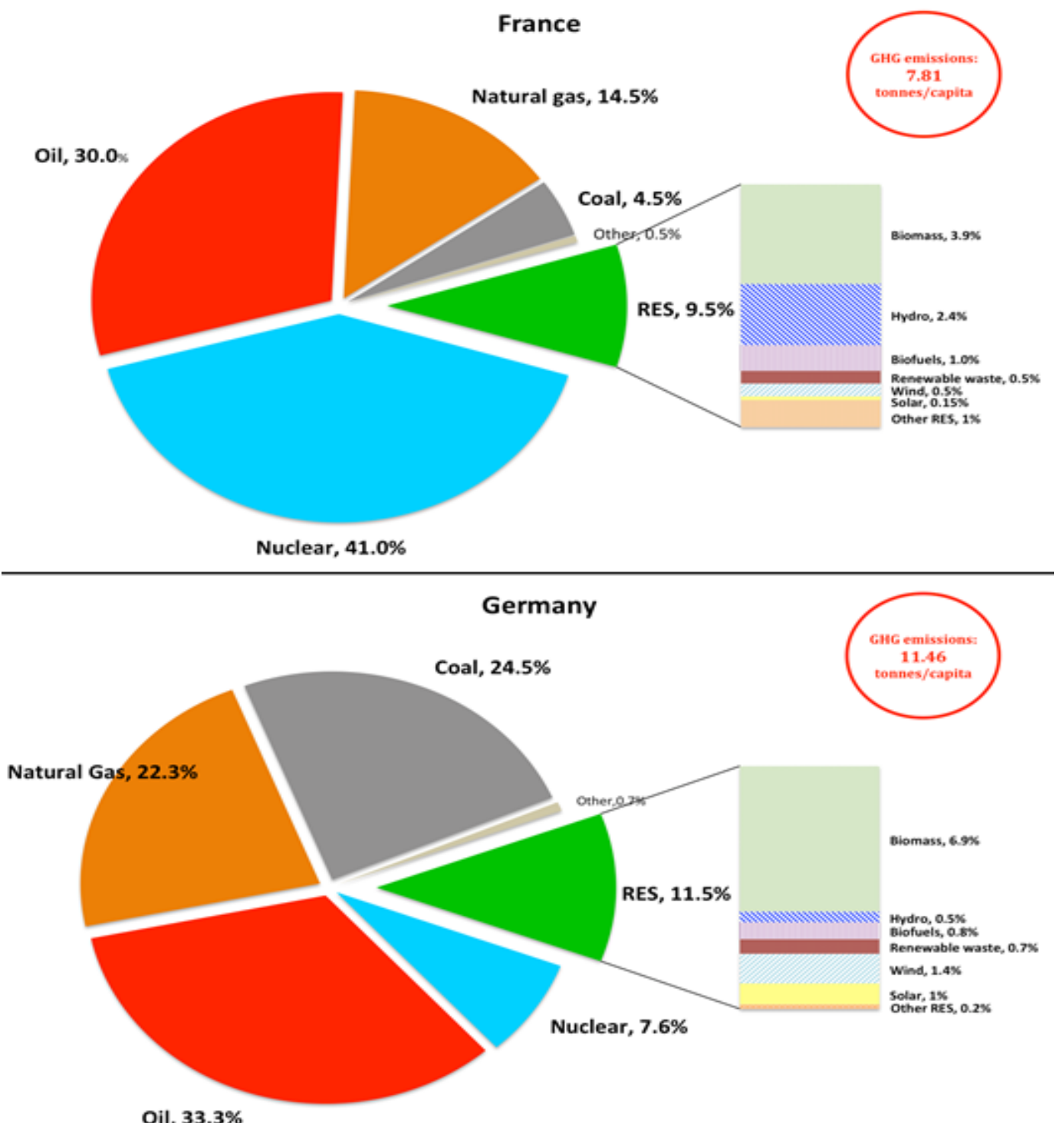

Figure 11. Mixes of energy in France and Germany

Source: http://blog.iass-potsdam.de/2015/05/energy-transition-france-following-in-germanys-footsteps/ 
As underlined, no other country in the world employs nuclear power to such an extent (Figure 11), allowing France to avoid lost of CO2:s. But the Green movement's criticism of nuclear power is based upon entirely different argument than the wish to decarbonise economy and society. Actually, doing both-decarbonisation and de-nuclearisation-may prove difficult for France. The French energy sector-EDF and AREVA-has suffered immensely from lower energy prices and scepticism about nuclear power, requiring massive state support.

\section{Hardly Promising Cases}

One finds that the emissions of CO2:s follows economic development closely in many countries, like China, South Koreas and most Latin American countries. The basic explanation is population growth and GDP growth - more people breathing and searching for higher life style. Take the case of China, whose emissions are the largest in the world, totally speaking (Figure 12). Interestingly, China has begun a fundamental change of its energy policy in 2015, reacting to mostly domestic demands for cleaner air and environment.

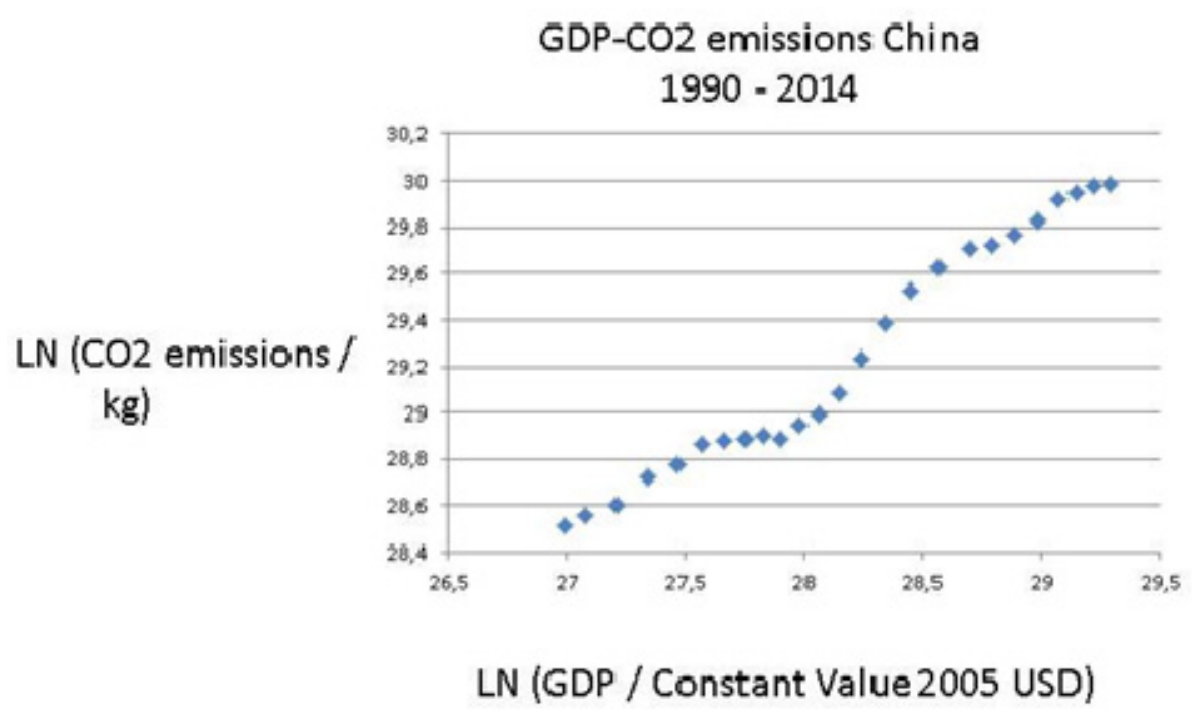

Figure 12. China: LN (CO2/ Kg and LN (GDP / Constant Value 2005 USD) (y=0,7x; R²=0,97)

The sharp increase in $\mathrm{CO} 2$ :s in China reflects not only the immensely rapid industrialization and urbanization of the last 30 years, but also its problematic energy mix (Figure 13), which is now up for overhaul.

\section{China energy consumption 2014}

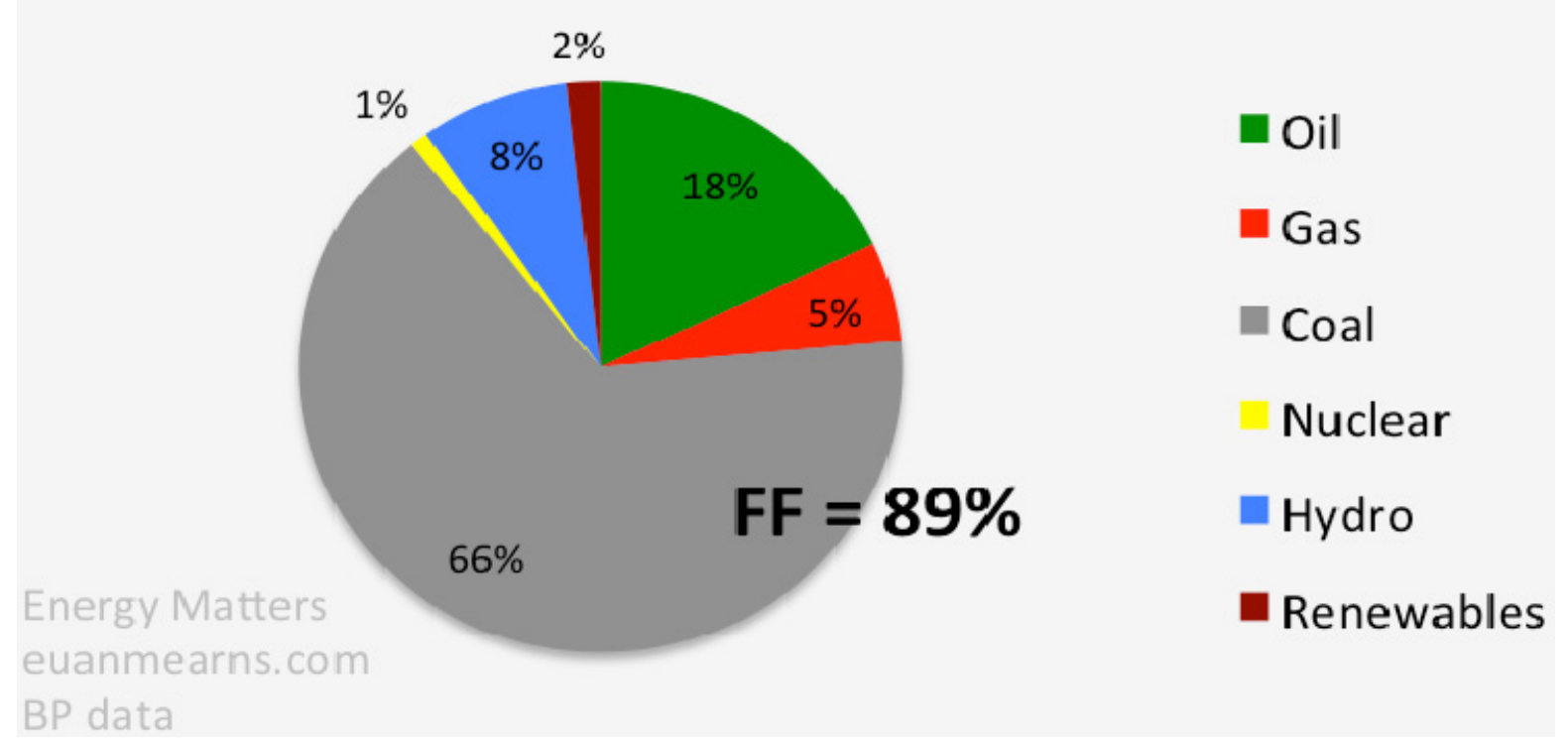

Figure 13. Mixes of energy in China

Source: http://euanmearns.com/china-post-industrial-revolution/ 
Almost 70 per cent of the energy consumption comes from the burning of coal with an additional 20 per cent from other fossil fuels. The role of nuclear is very small indeed but about to change. Numerous solar power plants as well as wind plants are constructed, as old coal fired stations are phased out.

Yet, this energy mix makes China very vulnerable and responsive to demands for radically cutting CO2 emissions: use other energy sources or install massively highly improved filters for carbon capture. It is true that China has turned to wind power, solar power and nuclear power on a huge scale recently, but the task of achieving a $40 \%$ reduction is enormous - GOAL II. China evidently hopes to respect its COP21 commitments while still enjoying an economic growth rate around $5 \%$, but it is realistic? New coal plants have actually been opened recently, replacing out-dated old ones in order to propel growth.

Decarbonisation $\mathrm{n}$ China will probably not achieve GOAL II, because CO2 emissions are increasing in the transportation sector with the car market becoming the biggest in the world and air transportation exploding. What is saved in one sector is dissipated in another.

Several small countries have much higher emissions per capita than China, and also giant USA this raises the enormously difficult problematic in COP21 management of fair cuts of emissions. Should the largest polluters per capita like the rich Gulf States cut most or the biggest aggregate polluters, like emerging economies China, India and Indonesia for instance? At COP21 negotiations in Paris, this issue about redistribution was resolved by the creation of a super fund to assist energy transition and environment protection in developing counties, as proposed early by economist Stern (2007)

Let us here look at the ethanol country par preference: Brazil. Figure 14 shows a considerable levelling out of total emissions, but it is followed by huge increases, mirroring the GDP development.

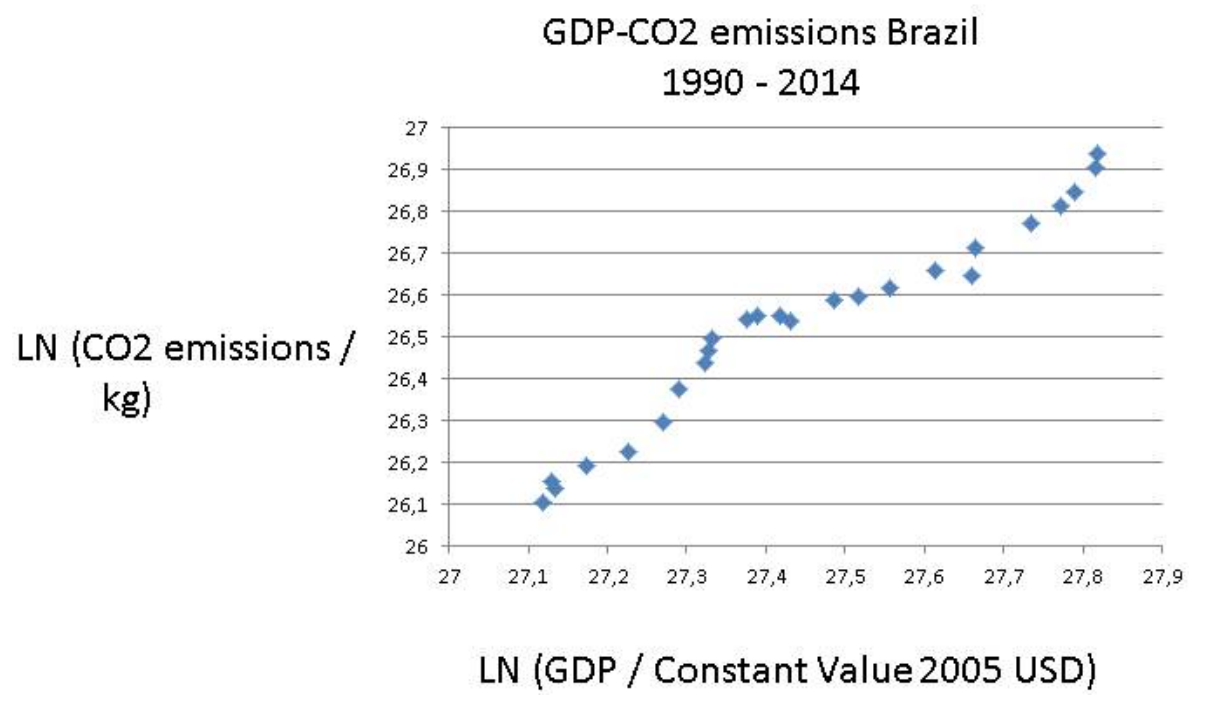

Figure 14. BRAZIL: LN (CO2 / Kg and LN (GDP / Constant Value 2005 USD) $\left(\mathrm{y}=1,029 \mathrm{x}-1,72 ; \mathrm{R}^{2}=0,95\right)$

Brazil employs the most biomass in the world - ethanol, but the emissions stay at a very high level, which is a reminder that even modern renewables may lead to $\mathrm{CO} 2$ :s. One advantage for Brazil is its large component of hydro power, but the overall picture for the largest Latin American country is not wholly promising, when it comes to reduction of emissions. Will it accomplish GOAL I - maybe! But hardly GOAL II. Two caveats:

-Global warming reduces the potential for hydro power - water scarcity, and Brazil has very little nuclear power (Figure 15). There are plans for mega hydro projects in the Amazon basin, but Brazil has first and foremost to come to terms with the extensive deforestation of this huge rain forest, contributing a lot to global warming. And other nations are involved here.

-Biomass and waste only contribute to decarbonisation when there is a sequence of harvesting and build-up of new carbon consuming entities. When the rain forest is cut down once and for all, or poisinous waste burnt, then there is carbonisaton. Ethanol fulfils decarbonisation. 


\section{Brazil energy consumption 2013}

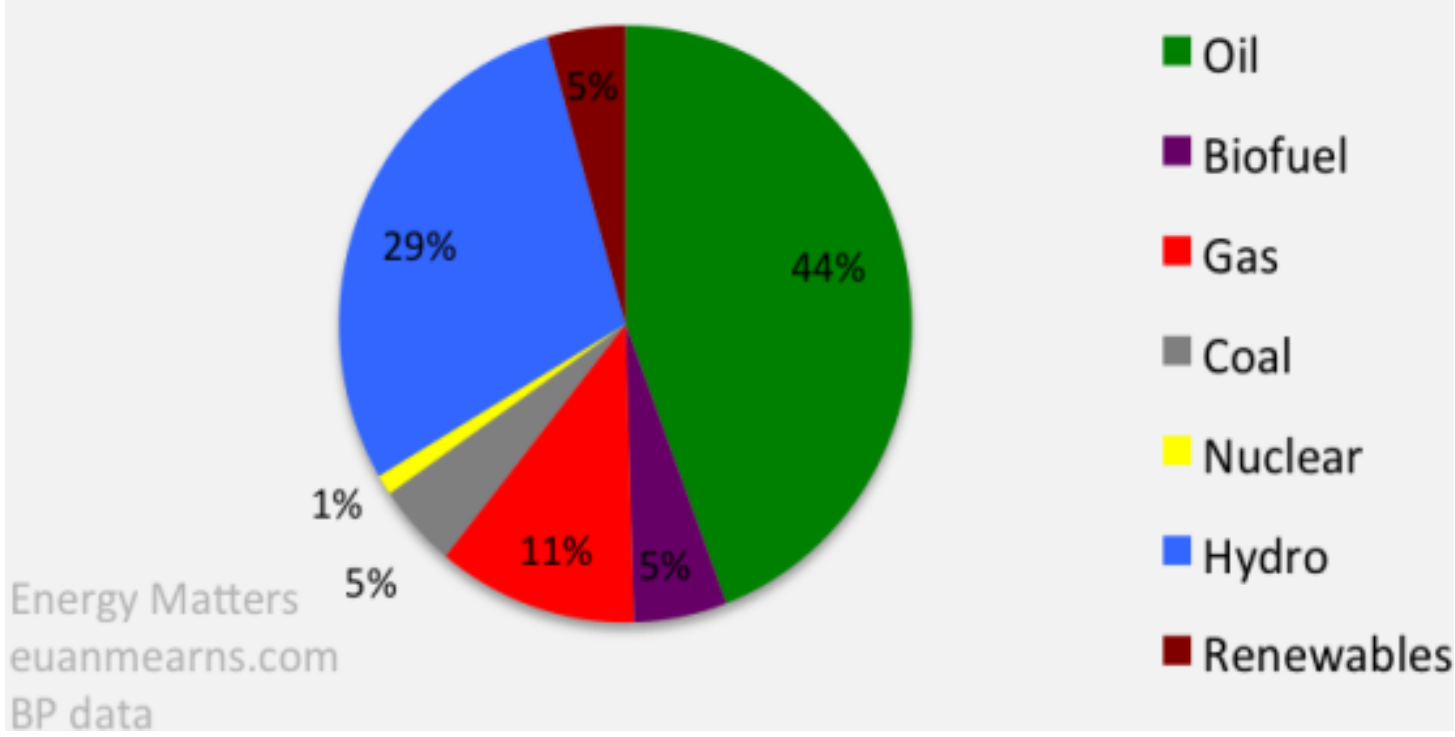

Figure 15. Mixes of energy in Brazil

I believe most "emerging economies" will rely much upon fossil fuels, like the examples above. One finds no example of declining GDG-CO2(GHG) links in Latin American nations, nor in Africa or Asia, meaning that COP21 management will struggle to get GOAL I implement.

\section{Certainly Not Promising Cases}

India will certainly appeal to the same problematic, namely per capita or aggregate emissions. The country is even more negative than China to cut $\mathrm{CO} 2$ emissions, as it is in an earlier stage of industrialization and urbanization. Figure 16 shows the close connection between emissions and GDP for this giant nation.

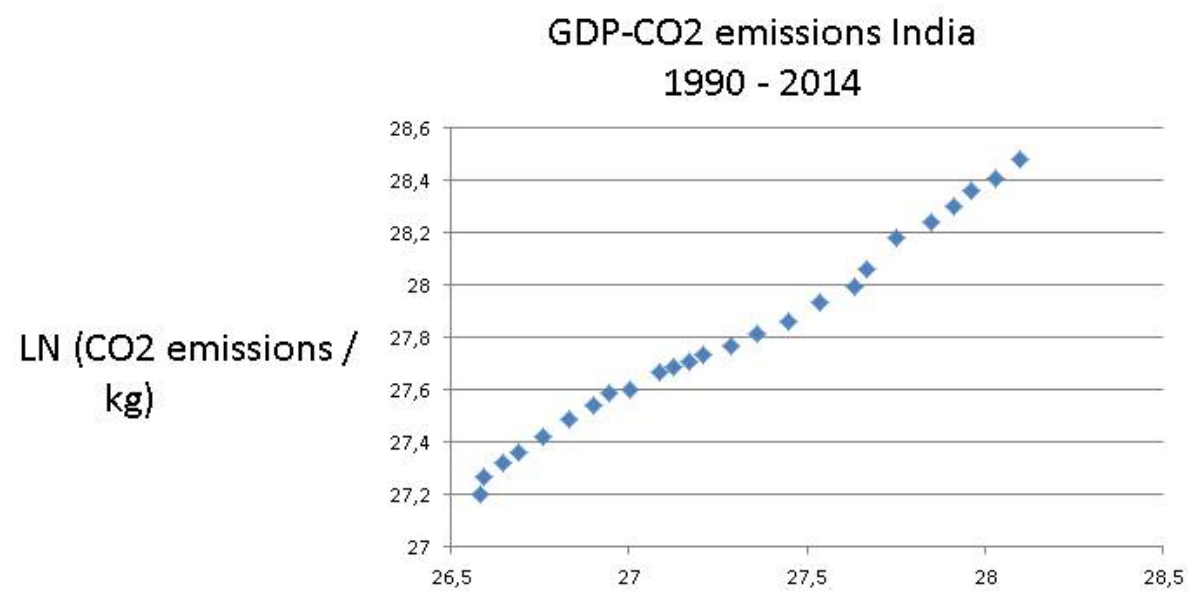

LN (GDP / Constant Value 2005 USD)

Figure 16. INDIA: LN (CO2/ Kg and LN (GDP / Constant Value 2005 USD) $\left(y=0,77 x+6,79 ; \mathrm{R}^{2}=0,99\right)$

India needs cheap energy for its industries, transportation and heating as well as air-conditioning, meaning it aims strongly at electrification. From where will this power come? India has water power and nuclear energy, but relies most upon coal, oil and gas as power source. It has strong ambitions for the future expansion of energy, but how is it to be generated, the world asks. India actually has small numbers for energy per capita, although it produces much energy totally. Figure 16 shows its energy mix where renewables play a bigger role than in China. However, the renewables in India may lead to deforestation and considerable pollution. 

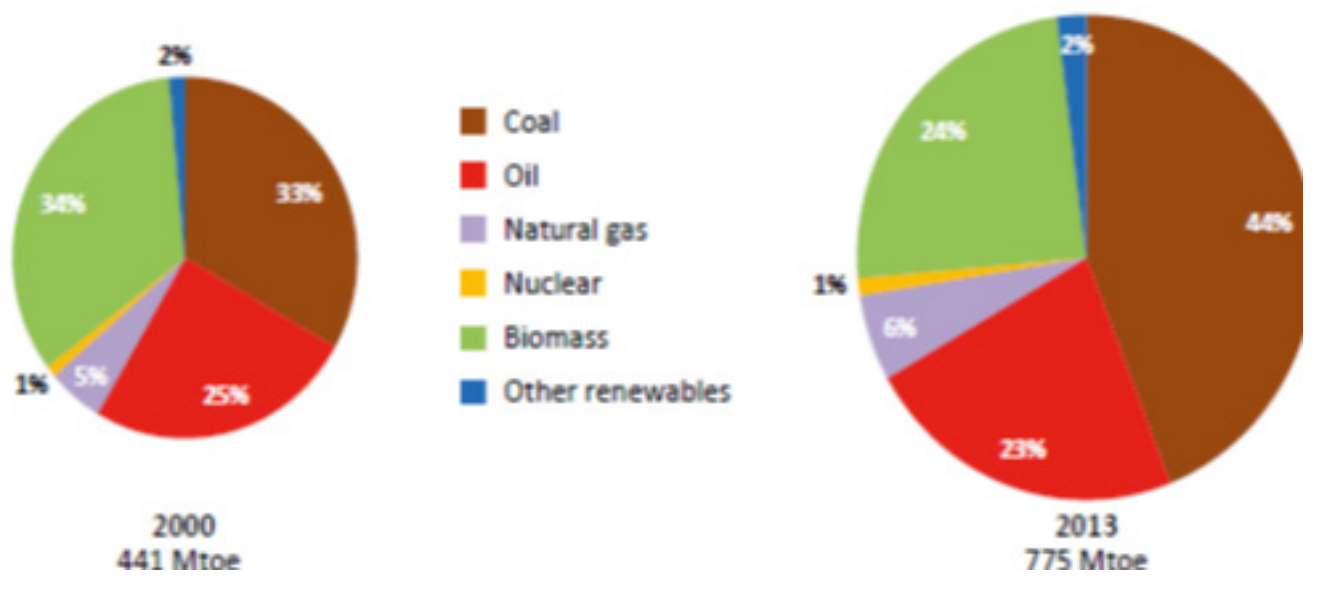

Figure 17. Energy mix for India

Source: http://www.eia.gov/beta/international/analysis.cfm?iso=IND

India needs especially electricity, as 300 million inhabitants lack access to it. The country is heavily dependent upon fossil fuels (70 per cent), although to a much less extent than China. Electricity can be generated by hydro power and nuclear power, both of which India employs. Yet, global warming reduces the capacity of hydro power - water shortages - and nuclear power meets with political resistance. Interestingly, India uses much biomass and waste for electricity production, which does not always reduce $\mathrm{CO} 2$ emissions. India's energy policy will be closely watched by other governments and NGO:s after 2018. The constant tension between the demand for economic growth on the one hand and environmental protection on the other hand is sharply portrayed in Ramesh (2015).

One may guess correctly that countries that try hard to "catch-up" will have increasing emissions. This was true of China and India. Let us look at three more examples, like e.g. giant Indonesia - now the fourth largest emitter of CO2:s in the world.

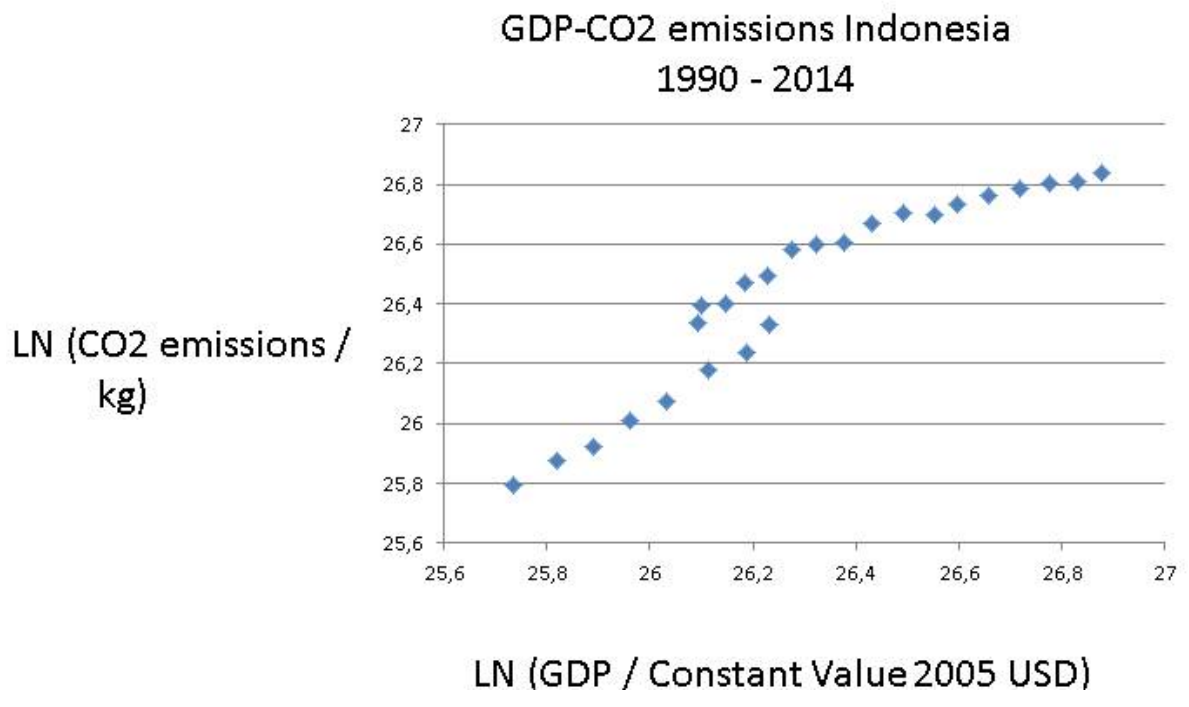

Figure 18. INDONESIA: LN (CO2 / Kg and LN (GDP / Constant Value 2005 USD) (y=1,69x; $\mathrm{R}^{2}=0,90$ )

Indonesia is a coming economic giant. Figure 18 reminds of the upward trend for China and India. However, matters are even worse for Indonesia, as the burning of the rain forest on Kalimantan augments the $\mathrm{CO} 2$ emissions very much. Figure 19 presents the energy mix for this huge country in terms of population and territory. 


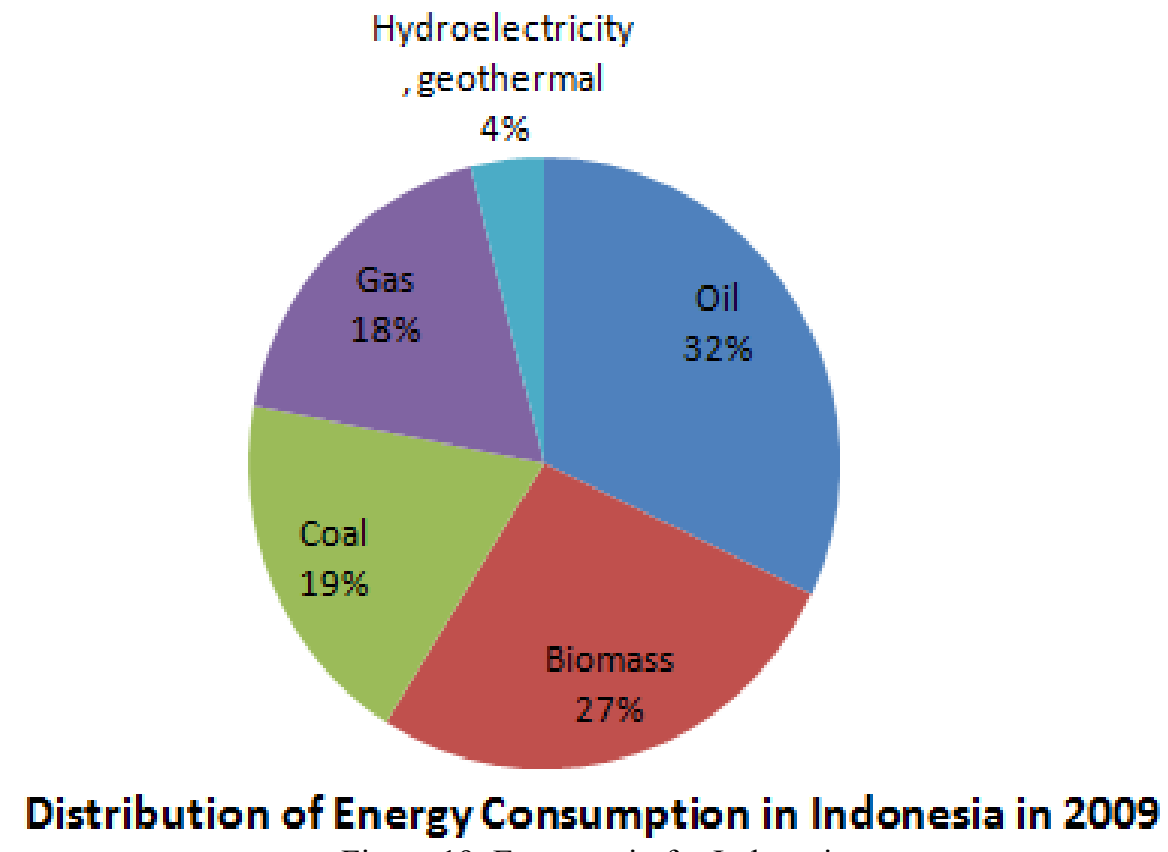

Figure 19. Energy mix for Indonesia

Source: (http://missrifka.com/energy-issue/recent-energy-status-in-indonesia.html)

Only 4 per cent comes from hydro power with 70 per cent from fossil fuels and the remaining 27 per cent from biomass, which alas also pollutes, especially traditional renewables like charcoal and dung.

Neither India nor Indonesia will reach GOAL I and GOAL II. They need huge financial support from the Supe Fund, as they not only utilise carbon full energy but also burns down forests, adding to deforestation and desertification.

The same upward trend GDP-C O2 holds for another poor developing country with huge population, namely Pakistan: LN (CO2 / Kg and LN (GDP / Constant Value 2005 USD) ( $\left.\mathrm{y}=1,05 \mathrm{x}-0,97 ; \mathrm{R}^{2}=0,96\right)$. The amount of CO2 emissions is high for Pakistan, viewed as aggregate. Pakistan is mainly reliant upon fossil fuels, but not coal among them (Figure 20). Actually, it has a rather mixed bag of energy sources.

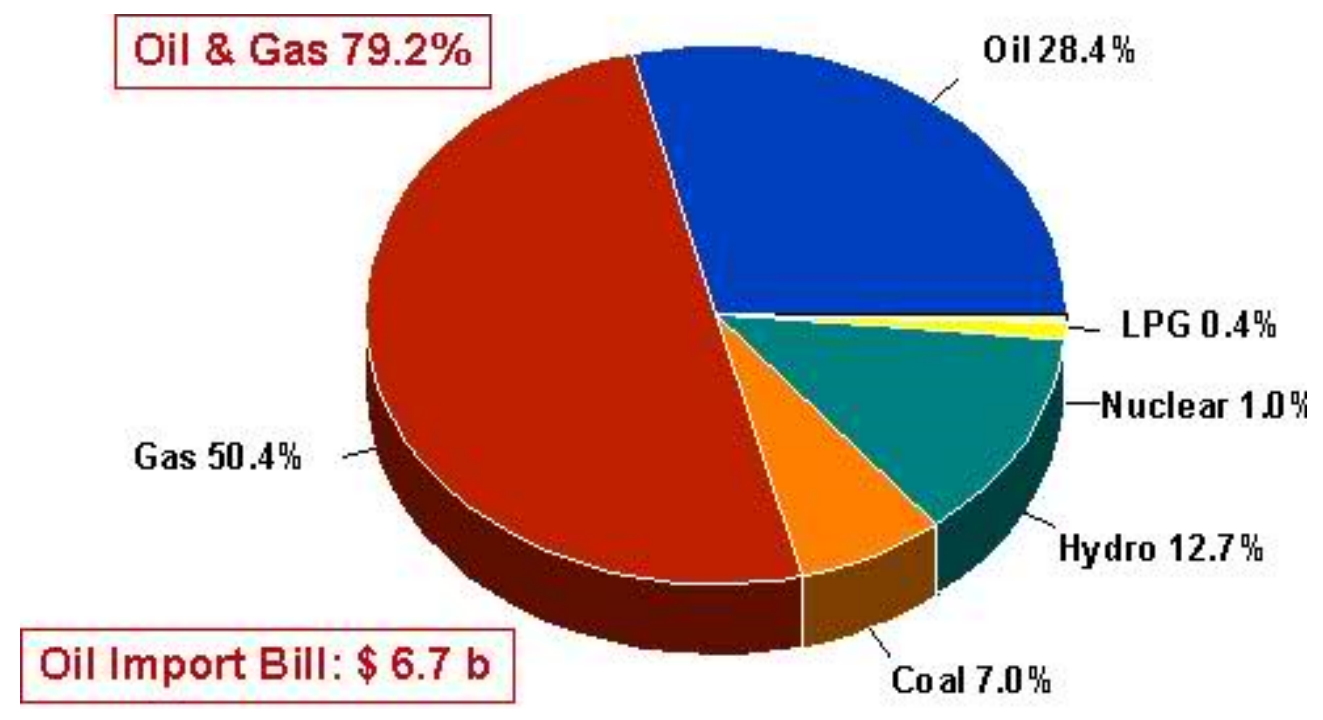

Figure 20. Pakistan Energy Consumption 2009 (by ShoXee: http://27.tinypic.com/2h6cyag.jpg)

But Pakistan employs a considerable portion of hydropower - 13 per cent - and a minor portion of nuclear power. Can it further develop nuclear and hydro power, or start using solar power on a large scale? Perhaps it will face frustration like India, as water shortages augment? 


\section{Certainly Unpromising Cases}

Countries may rely upon petroleum and gas mainly - see Iran (Figures 21 and 22). CO2 emissions have generally followed economic development in this giant country, although there seems to be a planning out phase recently, perhaps due to the international sanctions against its economy.

GDP vs. CO2 emissions Iran 1990-2014

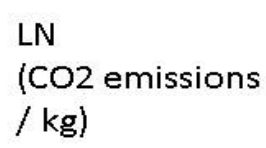

$\mathrm{LN}$ $/ \mathrm{kg}$ )

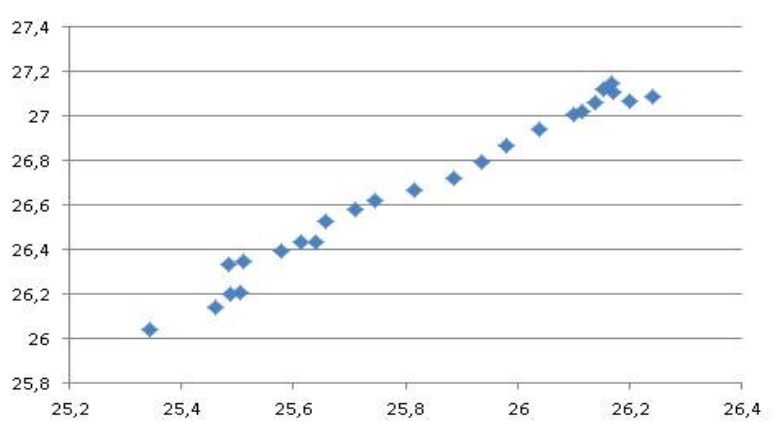

LN (GDP / (Constant Value 2005 USD))

Iran is together with Russia and Qatar the largest owner of natural gas deposits in the world. But despite using coal in very small amounts, its $\mathrm{CO} 2$ emissions are high. Natural gas pollute less than oil and coal, but if released unburned it is very dangerous as a greenhouse gas.

Methane is better than oil, which is better than coal, from the point of view of decarbonisation. But when a nation burns a lot of it, like Qatar, then $\mathrm{CO} 2$ emissions skyrocket just the same.

When countries are exclusively dependent upon either natural gas or petrolium, they are not likely to accomplish GOAL I or GOAL II. Iran could try other energy sources (Figure 22) - solar, atomic - but the first resource is costly and the second resource has proved very controversial from the point of view of international relations.

\section{Iran's total primary energy consumption, share by fuel 2013}
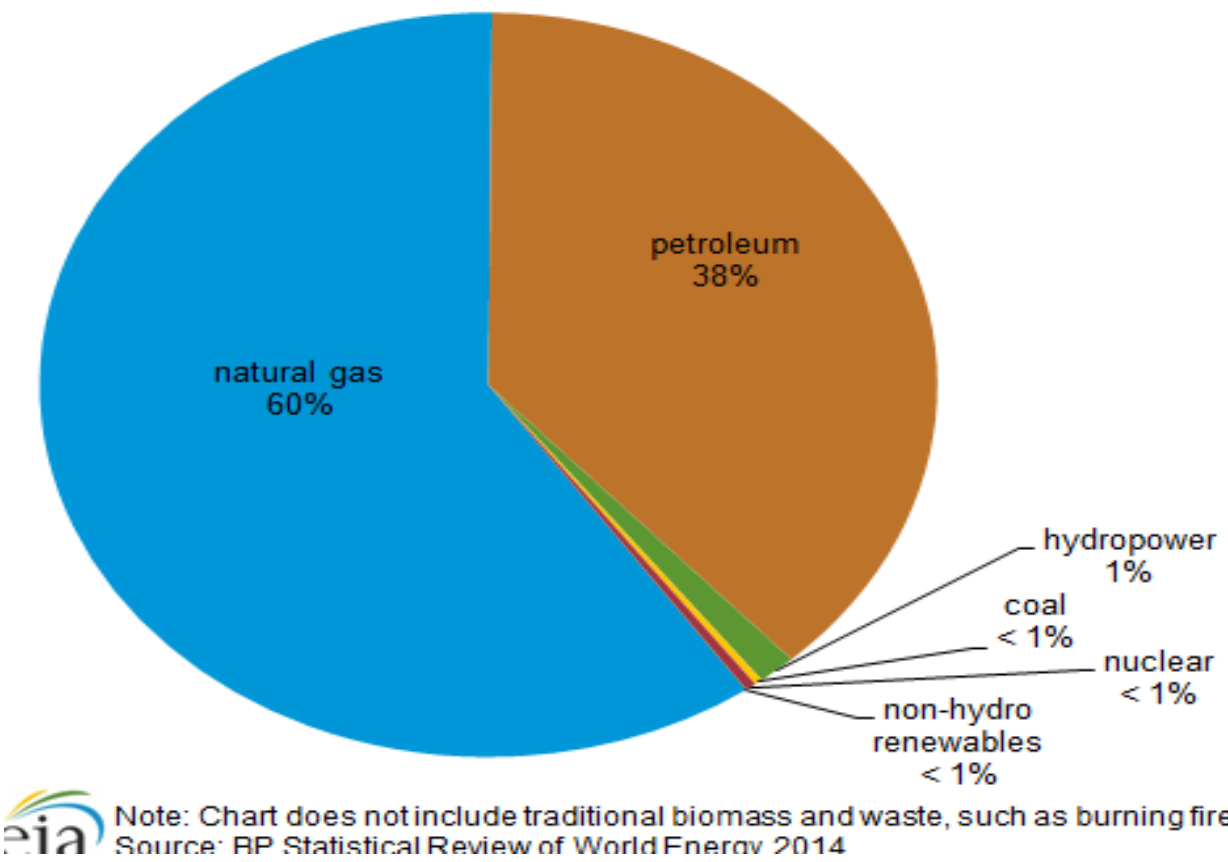

Note: Chart does not include traditional biomass and waste, such as burning firewood and waste. Source: RP Statistical Review of World Fnerav 2014

Figure 22. Energy mix for Iran

One would expect to find huge $\mathrm{CO} 2$ emissions in this large emerging economy with lots of oil production. Countries like the Gulf States have massive $\mathrm{CO} 2$ :s because they drill and refine oil and natural gas. For Mexico holds the following situation (Figure 23)). 
GDP - CO2 for Mexico $1990-2014$

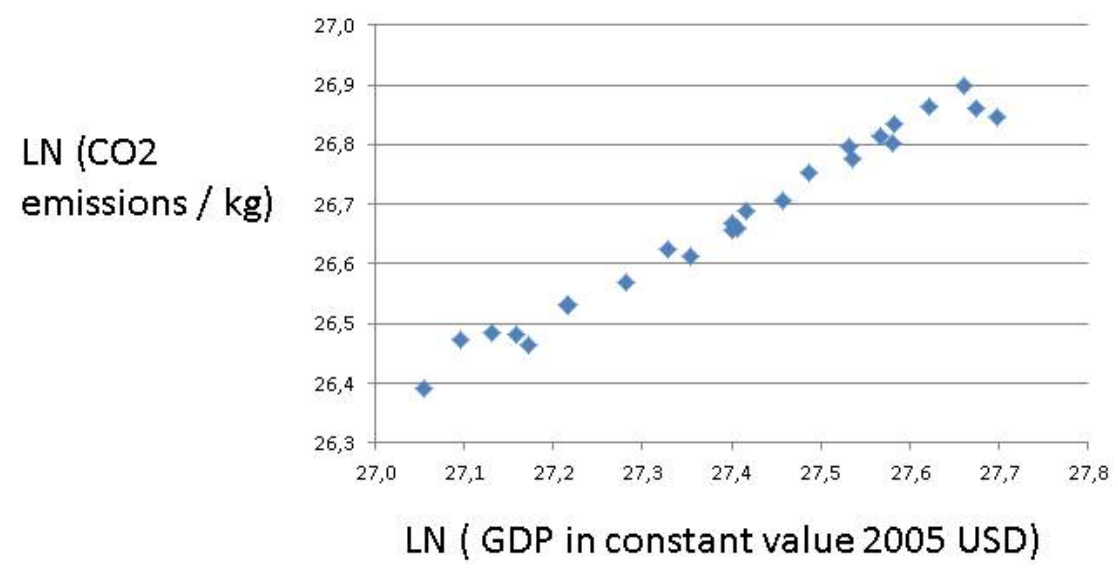

Figure 23. GDP-CO2 in Mexico: $\mathrm{y}=0,77 \mathrm{x} ; \mathrm{R}^{2}=0,98$

The close link between economic development and $\mathrm{CO} 2$ is discernable in the data, but the emissions' growth seems to stagnate in the last years. This is of course a promising sign, whether it is the start of a COP 21 inspired $40 \%$ reduction in $\mathrm{CO}$ :s remains to be seen. I doubt so, but let us enquire into the energy mix of this huge country that is of enormous economic importance to both North and South America.

\section{Total energy consumption in Mexico by type, 2014}

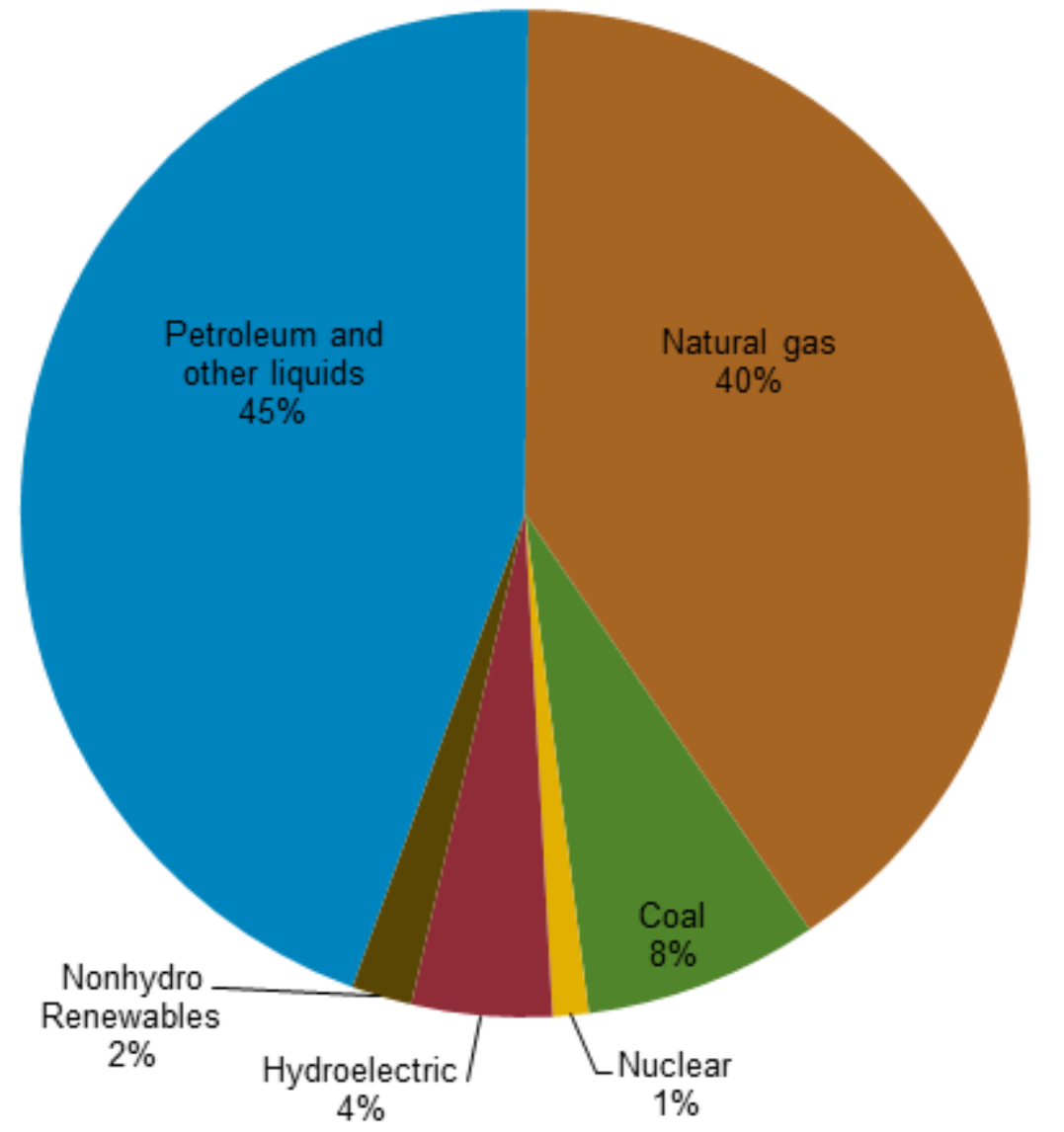

eia Source: U.S. Energy Information Administration, BP Statistical Review

Figure 24. Energy mix for Mexico 
Few countries are so depend upon fossil fuels as Mexico. One finds the same pattern with the Gulf States. The Mexican government must start now to reduce this dependency, by for instance eliminating coal and bringing down petreoleum and natural gas, instead betting upon solar, wind and nuclear power. Mexico will face severe difficulties with the $40 \%$ reduction target in COP21 - GOAL II. It has a fast growing population with many in poverty and an expanding industry sucking electricity. Can economic growth and decarbonisation go together here? GOAL I is hardly achievable here.

\section{COP21 Management: Logical or Illogical?}

There are signs that COP21 management is under way, both nationally and internationally. Some governments declare that they have already or will soon reach the GOAL I, sometime correct but sometimes just make belief. Other governments can do nothing, because they do not rule states. Typical is verbal commitment to decarbonisation at the same time as the requirement of economic developments trump environmental exigencies. Just consider the expansion of the transportation sector! Moe and more airtraffic is planned for. And also electricity cars have to have their energy from some power source for electricity. On the international scene, meetings continue under the auspicies of the UN and a French led secretariat. COP21 management is confronted by two major difficulties, namely to undo the typical link between GDP and energy on the one hand and GDP and GHG emissions on the other hand. Otherwise, none of the chief objects-COAL I, GOAL II and GOAL III-can be met. From what is known and experienced, these links can be undone in single micro projects, but not on the macro level, at least not on a scale required to narrow down climate change.

\section{Conclusion: The Super Fund}

The Third World is heavily into the use of fissil fuels. They can only change that when provided financial assistance. Here is where the super fund comes, It has been mentioned the phenomenal sum of 100 billion dollars/year. But no binding decisions have been takes about its structure and operations. What it entails is that rich countries pay for the decarbonisation of the poor countries. This fund would help COP21 management, but it may also create its own difficult problematic to handle. At this point of tine, there are many unknown in the conditions for COP21 management: the fund, the use of plan or market means, carbon trading schemes, carbon taxation schemes, oversight techniques and correction mechanisms. Look finally at Canada from COP21 management's perspective.

Although Canada is a major emitter of GHG:s as well as one of the world's largest fossil fuel producer - oil sands, it has managed to stem the increase in emissions for the most recent years, i.e. halting the augmentation, at least for a time (Figure 21). Figure 25 may be invoked to explain this, showing a very mixed energy consumption pattern with lots of different energy sources.

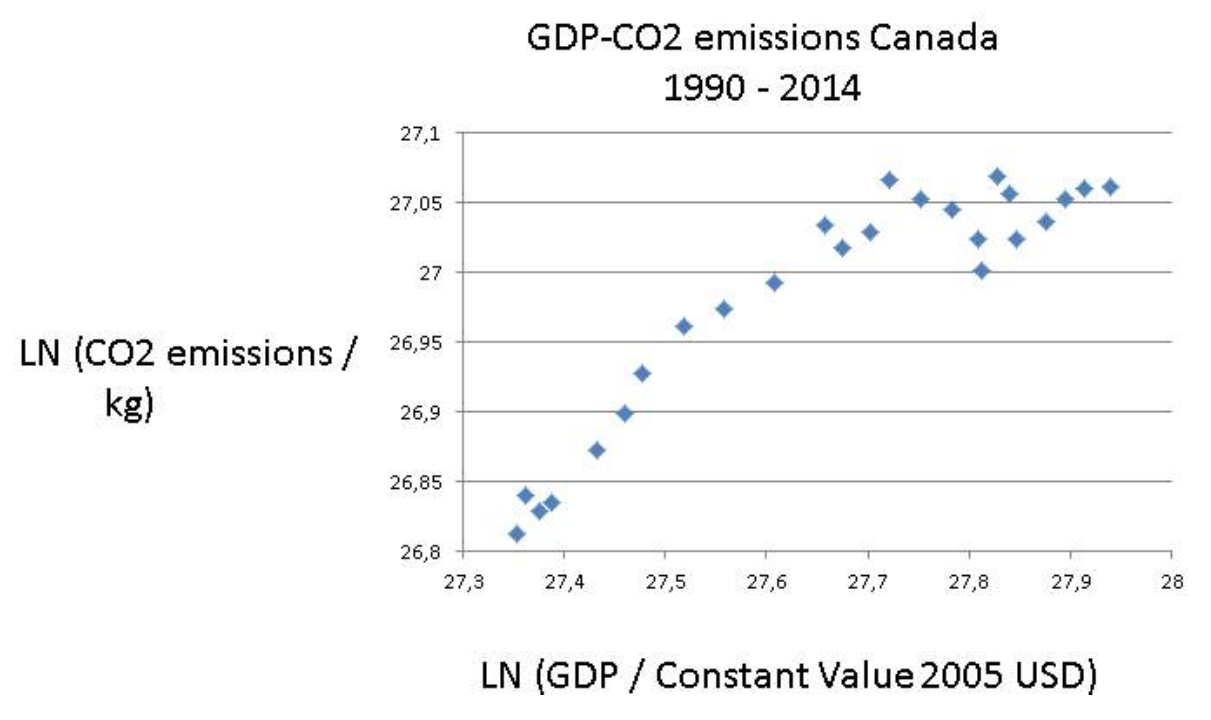

Figure 25. Canada: LN (CO2 / Kg and LN (GDP / Constant Value 2005 USD) ( $\mathrm{y}=0,41 \mathrm{x}+15,7 ; \mathrm{R}^{2}=0,85$ )

Canada has a strong advantage compared with for instance China and India in that it has access to lots of hydro power and natural gas. The burning of coal is as low as 12 per cent, but oil still makes up almost a third of energy consumption. But its emissions still go up with GDP. How to break this dire link - that is the crux of the matter?! 


\section{Canadian Energy Consumption by Primary Type}

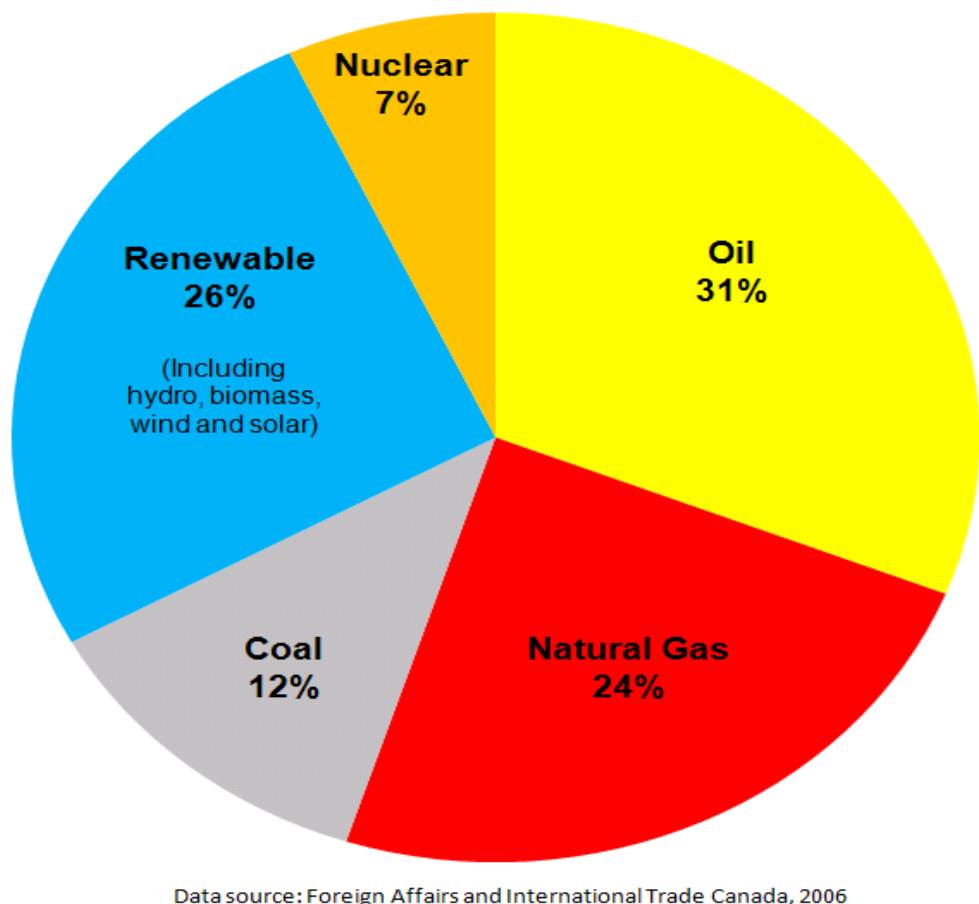

Figure 26. Canada's energy mix

Canada has not yet like the US managed to clearly and definitely turn the links-GDP-energy, GDP emissions downwards. The collapse of the oil price should make Canada invest more in water and modern renewables or atomic power (Figure 26).

Summing Up: It is crystal clear that global decarbonisation will prove very difficult, especially under the restraint of continued economic growth with more demand for energy. The many Third World nations will have to bet upon the Super Fund, but can really the First World muster that amount of money promised for such a long time? And can it be managed without embezzlement, patronage and kickbacks? With so many changes in country energy mixes over a short time span, transaction costs must go up with all claims and counter-claims between the COP21 secretariat and the governments of the world.

\section{References}

\section{GDP sources:}

World Bank national accounts data - data.worldbank.org

OECD National Accounts data files

\section{GHG sources:}

World Resources Institute CAIT Climate Data Explorer - cait.wri.org

EU Joint Research Centre Emission Database for Global Atmospheric

Research-http://edgar.jrc.ec.europa.eu/overview.php

UN Framework Convention on Climate Change-

http://unfecc.int/ghg_data/ghg_data_unfccc/time_series_annex_i/items/3814.php

International Energy Agency, Paris.

Energy Information Administration, Washington, DC.

BP Energy Outlook 2016.

\section{Literature}

de Bruyn, S. M. (2012). Economic Growth and the Environment: An Empirical Analysis. Berlin: Springer. 
Eriksson, C. (2013). Economic Growth and the Environment: An Introduction to the Theory. Oxford: OUP. http://dx.doi.org/10.1093/acprof:osob1/9780199663897.001.0001

Lomborg, B. (2007). Cool It. The Sceptical Environmentalist's Guide to Climate Change. New York: Alfred Knopf.

Managi, S. (2015). The Routledge Handbook of Environmental Economics in Asia. London: Routledge.

March, J., \& Olsen, J. P. (1976). Ambiguity and Choice. Oslo: Universitetsforlaget, Pressman, J. and A. Wildavsky $(1973,1984)$ Implementation. Berkeley: University of California Press.

Mazmanian, D. A., \& Sabatier, P. A. (1989). Implementation and Public Policy. Lanham, MD: UPA.

Pressman, J., \& Wildavsky, A. (1973, 1984). Implementation. Berkeley: University of Cal Press.

Ramesh, J. (2015). Green Signals: Ecology, Growth and Democracy in India (2015). Oxford: Oxford University Press. http://dx.doi.org/10.1093/acprof:oso/9780199457526.001.0001

Ramesh, J. (2015). Green Signals: Ecology, Growth and Democracy in India. Oxford: Oxford U.P. http://dx.doi.org/10.1093/acprof:oso/9780199457526.001.0001

Sabatier, P. A. (1988). An advocacy coalition framework of policy change and the role of policy-oriented learning therein. Policy Sciences, 21, 129-168. http://dx.doi.org/10.1007/BF00136406

Sachs, J. (2015). Sustainable Development for Humanity's Future. http://jeffsachs.org/2015/08/sustainable-development-for-humanitys-future/

Sachs, J. (August 10th, 2015). Sustainable Development for Humanity's Future. http://jeffsachs.org/2015/08/sustainable-development-for-humanitys-future/

Sachs, J. D. (2015). The Age of Sustainable Development. New York: Columbia University Press.

Simon, J. L. (2003). A Life Against the Grain. Piscataway: Transaction Publishers.

Stern, N. (2007). The Economics of Climate Change. Oxford: OUP. http://dx.doi.org/10.1017/CBO9780511817434

Stern, N. (2007). The Economics of Climate Change. Oxford: OUP. http://dx.doi.org/10.1017/CBO9780511817434

Wildavsky, A. $(1979,1987)$. Speaking Truth to Power. Piscataway: Transaction Publishers.

Wildavsky, A. (1987). Speaking Truth to Power. Piscataway: Transaction.

Wildavsky, A. (1997). But Is It Really True? Cambridge, MA: Harvard U.P.

Williamson, O. (1973). Hierarchies and Markets. New York: Free Press.

\section{$(\mathrm{cc}) \mathrm{BY}$}

This work is licensed under a Creative Commons Attribution 3.0 License. 